\title{
Mummified Fetus and Two Live Fetuses in Labrador Bitch: A Special Case
}

\author{
Ankit Kumar Ahuja*, A.K. Singh, Narinder Kumar and Muddrangiah
}
Department of Veterinary Gynecology and Obstetrics, College of Veterinary Science, Guru Angad Dev Veterinary and Animal Sciences, Ludhiana, Punjab-141004, India
*Corresponding author

\begin{tabular}{|c|c|}
\hline & A B S T R A C T \\
\hline Keywords & \multirow{4}{*}{$\begin{array}{l}\text { Fetal mummification in canine is not so common. It happens when fetus } \\
\text { died after one third of pregnancy and fetal fluid gets resorbed leading to } \\
\text { shriveling placenta around the fetus. In canines papyreous type of } \\
\text { mummification takes place. In papyreous mummification the fetal fluid gets } \\
\text { resorbed and placenta becomes adhered to the fetus. Present case deals with } \\
\text { the successful management of canine fetal mummification along with } \\
\text { delivery of two live fetuses. }\end{array}$} \\
\hline $\begin{array}{l}\text { Canine fetal } \\
\text { mummification, } \\
\text { Papyreous, } \\
\text { Resorption. }\end{array}$ & \\
\hline Article Info & \\
\hline $\begin{array}{l}\text { Accepted: } \\
\text { 19 June } 2017 \\
\text { Available Online: } \\
\text { 10 July } 2017\end{array}$ & \\
\hline
\end{tabular}

\section{Introduction}

Mummification is characterized by death of fetus and absorption of fetal fluid leading to contraction of uterus and fetal membranes become adhered to the fetus (Roberts, 2004). In the bitch stage at which the fetal death occur, decides whether resorption of fetus, mummification and abortion can occur. Fetal mummification usually occurs when the fetus died after first third of pregnancy and having a fully mature skin that is resistant to autolysis (Linde-Forsberg, 2010; Bindari and Shrestha, 2012). In multiparous animal if mummification occurs, it does not interfere with the survival of other viable fetuses; instead the mummified fetus may be delivered with the normal fetus at full term (Arthur et al., 2001).

\section{Case history and clinical examination}

A three year old Labrador bitch was presented in GADVASU clinic with the history of mating 70 days back. Anamneses revealed that the bitch was anorectic but no signs of impending whelping were visible. Rectal temperature was $104^{\circ} \mathrm{C}$ and other parameter show slight decrease from normal range. Blood picture revealed marked leukocytosis with neutrophilia suggesting an infection.

Ultrasonography revealed three fetal skeletons with the two normally developed and one underdeveloped. After stabilizing the bitch giving Ringer Lactate @ 150 ml intravenously, the bitch was put on cesarean section. 


\section{Treatment}

After giving pre anesthetic Atropine @ 0.04 $\mathrm{mg} / \mathrm{kg}$ S/C bitch was sedated using Xylazine @ $2 \mathrm{mg} / \mathrm{kg}$ and Ketamine @ $10 \mathrm{mg} / \mathrm{kg}$ and mid ventral laparotomy was done. After incising the muscle layer, uterus was visible and it shows mummified fetus was stuck at the uterine bifurcation leading to inability of other two fetuses to come out (Fig. 1). Uterine incision was made on the dorsal aspect of the uterine horn. Three fetuses were delivered with two completely normal and one mummified (Fig. 2). Uterus was sutured using double layer of Lambert and Cushing suture using Chromic catgut No. 2-0 and muscle layer was sutured by interrupted suture pattern using Vicryl suture no. 1-0. Skin sutures were applied by silk. The bitch was given antibiotic injection Cefotaxim $325 \mathrm{mg}$ $\mathrm{I} / \mathrm{M}$, injection Melonex @ $3 \mathrm{ml} \mathrm{I} / \mathrm{M}$, injection Polybion@ $2 \mathrm{ml} \mathrm{I} / \mathrm{M}$ and DNS @ $150 \mathrm{ml} / \mathrm{V}$. Whole of the treatment was continued for five days except the fluid therapy. Skin sutured was removed after 14 days.

\section{Results and Discussion}

Death of fetus can occur at any stage of pregnancy and can result in resorption, abortion or retention of fetus which can become mummified or if bacterial contamination occur leads to maceration or pyometra (Mudasir et al., 2012).

Fig.1 Mummified Fetus showing embryonic remnant of body parts

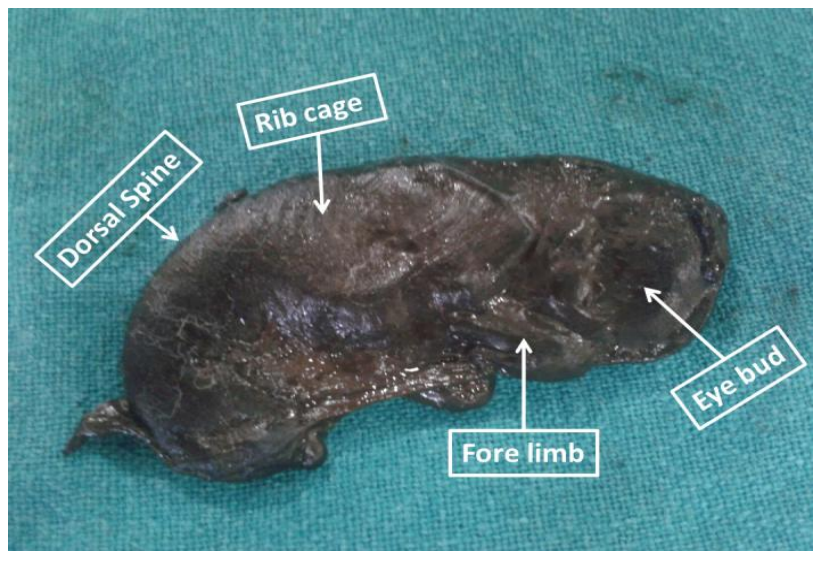

Fig.2 Mummified fetus with live fetus

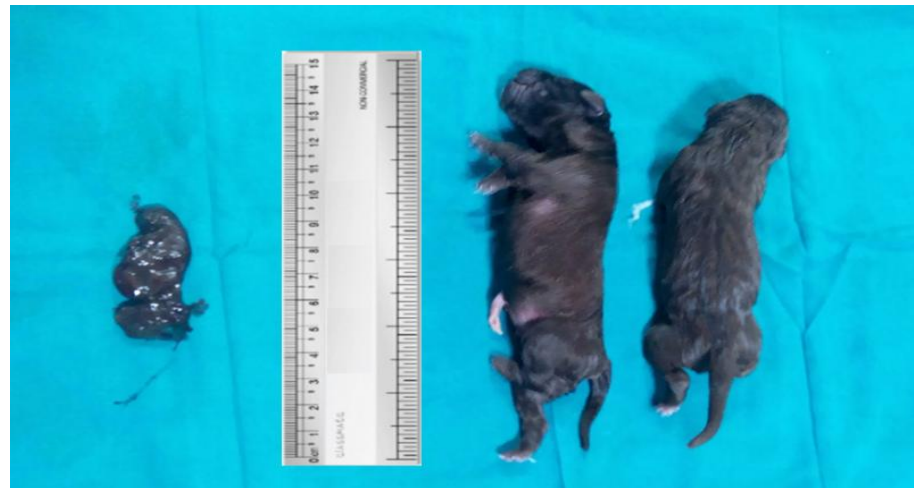

The nature of outcome depends on what has caused embryonic/fetal death, the stage of pregnancy and fetal/maternal immune- competence (Romagnoli, 2002). In bitch the main cause of fetal mummification is Canine Herpes Virus Infection (Arthur et al., 1996). 
Here one mummified fetus is delivered with two normal fetuses which clearly show that the presence of mummified fetus does not affect the viability of other live fetuses. The lack of expulsion of fetus may be due to primary uterine inertia (Vorwald et al., 2012). Scientists also believed that sometimes fetus fail to produce sufficient ACTH and cortisol which were the first signal given to mother for initiating the process of parturition (Johnston et al., 2001a; Linde- Forsberg, 2010). Reports of Walett and Lindane (1994) suggested uterine inertia as main cause of dystocia and retention of mummified fetus in bitches.

\section{References}

Arthur, G.H., Noakes, D.E., Pearson, H. and Parkinesen, T.J. 2001. Veterinary Reproduction and Obstetrics. W.B Saunders Company Limited. London. P137.

Arthur, G.H., Noakes, D.E., Pearson, H. and Parkinson, T.J. 1996. Vet. Reproduction and Obstertics, $8^{\text {th }}$ edition, WB Saunders Company Ltd, London.

Bindari, Y.R. and Shrestha, S. 2012. Canine fetal mummification. Inter. J. Vet. Sci., 1(1): $10-12$.
Linde-Forsberg, C. 2010. Abnormalities in pregnancy, parturition, and the periparturient period. In: Ettinger SJ and Feldmen J (editors), Textbook of Veterinary Internal Medicine. Elsevier Saunders, St Louis, Missouri, 7: 18901901.

Mudasir, Q., Shah, K.A., Nyrah, Q. and Andrabi, A. 2012. Fetal Mummification in Bitch. Vet. Scan, 7(1): 97-99.

Roberts, S.J. 2004. Vet. Obstetric and Genital Dis., 2nd edition.CBS Publishers and Distributors, India.

Romagnoli, S. 2002. Complications in canine pregnancy and their clinical approach. Proceedings of the Veterinary Sciences Congress, 2002, SPCV, Oeiras, 10-12 Out, pp. 159-162

Voorwald, F.A., Tiosso, C.F., Cardilli, D.J. and Toniollo, G.H. 2012. Mummified papyraceous fetuses in the abdominal cavity of an elderly female dog with pyometra. Arquivo Brasileiro de Medicina Veterinaria e Zootecnia, 64: 2.

Walett, D. and Lindane, F. 1994. Dystocia in bitch- a retrospective study of 182 cases. J. Small Animal Practice, 35(8): 402-407.

\section{How to cite this article:}

Ankit Kumar Ahuja, A.K. Singh, Narinder Kumar and Muddrangiah. 2017. Mummified Fetus and Two Live Fetuses in Labrador Bitch: A Special Case. Int.J.Curr.Microbiol.App.Sci. 6(7): 1642-1644. doi: https://doi.org/10.20546/ijcmas.2017.607.198 